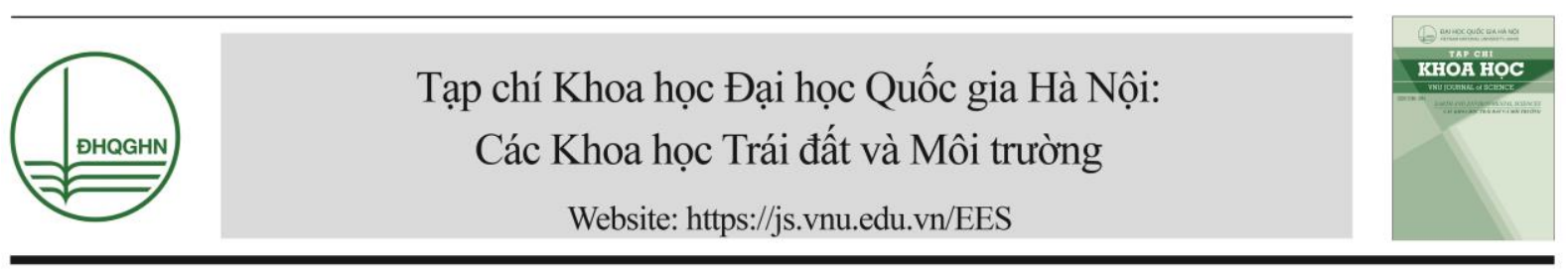

\title{
Nghiên cứu định lượng cacbon trong rừng ngập mặn ven biển xã Hải Lạng, huyện Tiên Yên, tỉnh Quảng Ninh
}

\author{
Nguyễn Thị Hồng Hạnh ${ }^{1, *}$, Lê Khánh Linh ${ }^{2}$, Phạm Hồng Tính ${ }^{1}$, \\ Lê Đắc Trường ${ }^{1}$, Bùi Thị Thư ${ }^{1}$, Trương Minh Tâm ${ }^{3}$ \\ ${ }^{1}$ Truò̀ng Đại học Tài nguyên và Môi trưòng Hà Nội \\ ${ }^{2}$ Phòng Tài nguyên và Môi truờng huyện Mộc Châu \\ ${ }^{3}$ Tổng Cục Môi trường \\ Nhận ngày 03 tháng 9 năm 2018 \\ Chỉnh sửa ngày 10 tháng 9 năm 2018; Chấp nhận đăng ngày 10 tháng 9 năm 2018
}

\begin{abstract}
Tóm tắt: Để đánh giá khả năng tạo bể chứa cacbon của rừng ngập mặn ven biển phục vụ quản lý nhà nước về giảm phát thải khí nhà kính, cung cấp cơ sở khoa học và thông tin cho các chương trình thực hiện cắt giảm khí nhà kính như REDD, $\mathrm{REDD}^{+}$, chúng tôi đánh giá khả năng tạo bể chứa cacbon của rừng ngập mặn ven biển xã Hải Lạng, huyện Tiên Yên, tỉnh Quảng Ninh với các loài đặc trưng như vẹt dù (Bruguiera gymnorhiza), đâng (Rhizophora stylosa), trang (Kandelia obovata), sú (Aegiceras corniculatum), mắm (Avicennia marina) thông qua 3 bể chứa cacbon của rừng: (1) Bể chứa cacbon trong thực vật ở trên mặt đất; (2) Bể chứa cacbon trong thực vật ở dưới mặt đất; (3) Bể chứa cacbon trong đất, dưới dạng cacbon hữu cơ theo hướng dẫn của IPCC (2006). Kết quả nghiên cứu cho thấy, lượng cacbon tích lũy trong đất rừng cao hơn khoảng 5 lần lượng cacbon tích lũy trong sinh khối thực vật trên mặt đất và dưới mặt đất của rừng. Lượng cacbon tích lũy trong đất rừng trung bình là 124,85 tấn/ha; Lượng cacbon tích lũy trong sinh khối thực vật trên mặt đất của rừng trung bình là 26,31 tấn/ha; Lượng cacbon tích lũy trong sinh khối thực vật dưới mặt đất của rừng trung bình là 24,35 tấn/ha. Tổng lượng cacbon tích lũy thông qua 3 bể chứa cacbon của đạt trung bình là 175,52 tấn/ha (tương ứng với lượng $\mathrm{CO}_{2}$ là 607,48 tấn/ha). Khả năng tích lũy cacbon trong rừng cao là cơ sở khoa học để xây dựng và thực hiện các dự án trồng rừng ngập mặn, kết hợp với bảo tồn, quản lý bền vững và tăng cường trữ lượng cacbon rừng trồng ở các dải ven biển Việt Nam.
\end{abstract}

Tù khóa: Avicennia marina, Aegiceras corniculatum, Bruguiera gymnorhiza, Kandelia obovata, Rhizophora stylosa, khí nhà kính, rừng ngập mặn, tích lũy cacbon.

\section{1. Đặt vấn đề}

Rừng ngập mặn (RNM) có ý nghĩa vô cùng quan trọng, góp phần phòng chống thiên tai,

\footnotetext{
*Tác giả liên hệ. ĐT.: 84-.

Email: nthhanh.mt@hunre.edu.vn

https://doi.org/10.25073/2588-1094/vnuees.4291
}

chống xâm nhập mặn, bảo vệ môi trường các vùng cửa sông ven biển, điều hòa khí hậu, chống gió bão, hạn chế xói lở đê biển, phòng chống xâm nhập mặn, giữ phù sa cho đất, tạo điều kiện cho đất liền lấn ra biển, tích lũy cacbon, góp phần làm giảm nồng độ khí nhà kính trong khí quyển. 
Nhận thấy tầm quan trọng của rừng trong việc ứng phó với biến đổi khí hậu, Ủy ban liên chính phủ về biến đối khí hậu (IPCC) đã đưa ra chương trình REDD (Reducing Emission from Deforestation and forest Degradation: Giảm thiểu khí thải do mất rừng và suy thoái rừng) và REDD $^{+}$(Giai đoạn sau của REDD, giảm phát thải khí nhà kính thông qua nỗ lực hạn chế mất rừng và suy thoái rừng, quản lý bền vững tài nguyên rừng, bảo tồn và nâng cao trữ lượng cacbon rừng). Theo hệ thống này, các nước sẽ đo đếm và giám sát lượng $\mathrm{CO}_{2}$ phát thải từ mất rừng và suy thoái rừng. Sau một giai đoạn nhất định, các nước sẽ tính toán lượng giảm phát thải và nhận được số tín chỉ cacbon rừng, từ đó có thể trao đổi trên thị trường dựa trên giảm thiểu này.

Rừng ngập mặn vùng cửa sông Tiên Yên được coi là hệ sinh thái rừng ngập mặn điển hình của khu vực phía Bắc Việt Nam. Để góp phần đánh giá khả năng tích lũy cacbon của rừng ngập mặn ven biển huyện Tiên Yên, tỉnh Quảng Ninh, chúng tôi thực hiện nghiên cứu định lượng cacbon trong rừng ngập mặn huyện Tiên Yên, tinh Quảng Ninh. Kết quả nghiên cứu nhằm cung cấp các số liệu khoa học, đánh giá khả năng tích lũy cacbon của rừng ngập mặn ven biển, phục vụ quản lý nhà nước về giảm phát thải khí nhà kính, cung cấp cơ sở khoa học và thông tin cho các chương trình thực hiện cắt giảm khí nhà kính như REDD, REDD ${ }^{+}$, góp phần ứng phó biến đổi khí hậu.

\section{2. Đối tượng và phương pháp nghiên cứu}

\section{1. Đối tượng nghiên cưu}

Nghiên cứu trên đối tượng là cacbon trong sinh khối thực vật ở trên mặt đất; dưới mặt đất và cacbon trong đất dưới dạng cacbon hữu cơ theo hướng dẫn của IPCC (2006) của rừng ngập mặn xã Hải Lạng, huyện Tiên Yên, tỉnh Quảng Ninh. Địa hình khu vực nghiên cứu tương đối thấp và bằng phẳng, độ cao từ $1,5-3 \mathrm{~m}$, là vùng bồi tụ ven biển. Đây là một trong những khu vực có điều kiện tương đối thuận lợi cho cây ngập măn phát triển. Theo Ủy ban Nhân dân xã Hải Lạng, diện tích rừng ngập mặn tính đến năm 2014 là 656,5 ha. Các loài đặc trưng thực thụ thân ghỗ như vẹt dù (Bruguiera gymnorhiza), đâng (Rhizophora stylosa), trang (Kandelia obovata), sú (Aegiceras corniculatum), mắm (Avicennia marina).

Nghiên cứu được thực hiện từ tháng 5 năm 2017 đến tháng 5 năm 2018.

\subsection{Phuoong pháp nghiên cúu}

\section{Phuoong pháp bố trí thí nghiệm}

Thiết lập 3 tuyến nghiên cứu theo hướng từ đất liền ra phía biển tại khu vực rừng ngập mặn xã Hải Lạng, huyện Tiên Yên, tỉnh Quảng Ninh. Trên mỗi tuyến nghiên cứu, thiết lập 3 ô tiêu chuẩn, mỗi ô có diện tích $100 \mathrm{~m}^{2}(10 \mathrm{~m} \times$ 10m) (Nguyễn Thị Hồng Hạnh, 2009) [3]. Vị trí các ô tiêu chuẩn được thể hiện qua bảng 1 và hình 1.

Phương pháp xác định mật độ và đường kính thân cây

Xác định mật độ bằng cách đếm số cây trong mỗi ô tiêu chuẩn $\left(100 \mathrm{~m}^{2}\right)$, dựa trên số lượng cây trung bình trong 9 ô tiêu chuẩn, tính mật độ của cây rừng.

Xác định đường kính thân cây bằng thước dây đo đường kính (Forestry Suppliers Metric Fabric Diameter Tape Model 283d/5m) tại vị trí $30 \mathrm{~cm}$ phía trên bạnh gốc đối với các loài trang (Kandelia obovata) và vẹt dù (Bruguiera gymnorhiza), tại vị trí phía trên rễ chống cao nhất đối với đâng (Rhizophora stylosa) và tại vị trí $30 \mathrm{~cm}$ trên mặt đất đối với những loài còn lại.

\section{Phuơng pháp nghiên cứu sinh khối}

Sinh khối trên mặt đất và dưới mặt đất của cây trong các ô tiêu chuẩn được xác định bằng cách quy đổi từ đường kính thân cây theo các công thức sinh khối của Nguyễn Thị Hồng Hạnh và cộng sự (2016) [1] (đối với trang và bần chua) và của Komiyama và cộng sự (2008) [2] (đối với những loài còn lại). 
Bảng 1. Vị trí các ô tiêu chuẩn trong rừng ngập mặn xã Hải Lạng, huyện Tiên Yên

\begin{tabular}{|c|c|c|c|c|}
\hline $\begin{array}{l}\text { Tuyến } \\
\text { nghiên cứu }\end{array}$ & $\begin{array}{l}\text { Ô tiêu chuẩn } \\
(10 \mathrm{~m} \times 10 \mathrm{~m})\end{array}$ & Loài cây & Tọa độ & \\
\hline \multirow{3}{*}{1} & Ô 1 & $\begin{array}{l}\text { Vẹt dù (Bruguiera gymnorhiza), Đâng } \\
\text { (Rhizophora stylosa) }\end{array}$ & $21^{\circ} 15^{\prime} 06.3^{\prime \prime} \mathrm{N}$ & $107^{\circ} 21^{\prime} 51.8^{\prime \prime} \mathrm{E}$ \\
\hline & Ô 2 & $\begin{array}{l}\text { Vẹt dù (Bruguiera gymnorhiza), Đâng } \\
\text { (Rhizophora stylosa) }\end{array}$ & $21^{\circ} 15^{\prime} 07.8^{\prime \prime} \mathrm{N}$ & $107^{\circ} 21^{\prime} 54.0^{\prime \prime} \mathrm{E}$ \\
\hline & Ô 3 & $\begin{array}{l}\text { Vẹt dù (Bruguiera gymnorhiza), Sú } \\
\text { (Aegiceras corniculatum), Trang (Kandelia } \\
\text { obovata) }\end{array}$ & $21^{\circ} 15^{\prime} 10.5^{\prime \prime} \mathrm{N}$ & $107^{\circ} 21^{\prime} 57.2^{\prime \prime E}$ \\
\hline \multirow{3}{*}{2} & Ô 1 & $\begin{array}{l}\text { Vẹt dù (Bruguiera gymnorhiza), Đâng } \\
\text { (Rhizophora stylosa), Sú (Aegiceras } \\
\text { corniculatum), Trang (Kandelia obovata) }\end{array}$ & $21^{\circ} 15^{\prime} 31.3^{\prime \prime} \mathrm{N}$ & $107^{\circ} 21^{\prime} 48.6 " \mathrm{E}$ \\
\hline & Ô 2 & $\begin{array}{l}\text { Vẹt dù (Bruguiera gymnorhiza), Đâng } \\
\text { (Rhizophora stylosa) }\end{array}$ & $21^{\circ} 15^{\prime} 35.0^{\prime \prime} \mathrm{N}$ & $107^{\circ} 22^{\prime} 02.7^{\prime \prime E}$ \\
\hline & Ô 3 & $\begin{array}{l}\text { Vẹt dù (Bruguiera gymnorhiza), Đâng } \\
\text { (Rhizophora stylosa), Sú (Aegiceras } \\
\text { corniculatum), Trang (Kandelia obovata) }\end{array}$ & $21^{\circ} 15^{\prime} 39.4^{\prime \prime} \mathrm{N}$ & $107^{\circ} 22^{\prime} 09.2^{\prime \prime E}$ \\
\hline \multirow{3}{*}{3} & Ô 1 & $\begin{array}{l}\text { Vẹt dù (Bruguiera gymnorhiza), Trang } \\
\text { (Kandelia obovata) }\end{array}$ & $21^{\circ} 15^{\prime} 36.4^{\prime \prime} \mathrm{N}$ & $107^{\circ} 22^{\prime} 31.6^{\prime \prime E}$ \\
\hline & Ô 2 & $\begin{array}{l}\text { Vẹt dù (Bruguiera gymnorhiza), Đâng } \\
\text { (Rhizophora stylosa), (Aegiceras } \\
\text { corniculatum), Trang (Kandelia obovata), } \\
\text { Mắm (Avicennia marina) }\end{array}$ & $21^{\circ} 15^{\prime} 46.8^{\prime \prime} \mathrm{N}$ & $107^{\circ} 22^{\prime} 42.6^{\prime \prime E}$ \\
\hline & Ô 3 & $\begin{array}{l}\text { Vẹt dù (Bruguiera gymnorhiza), Đâng } \\
\text { (Rhizophora stylosa), Sú (Aegiceras } \\
\text { corniculatum), Trang (Kandelia obovata) }\end{array}$ & $21^{\circ} 15^{\prime} 52.3^{\prime \prime} \mathrm{N}$ & $107^{\circ} 22^{\prime} 48.2^{\prime \prime} \mathrm{E}$ \\
\hline
\end{tabular}

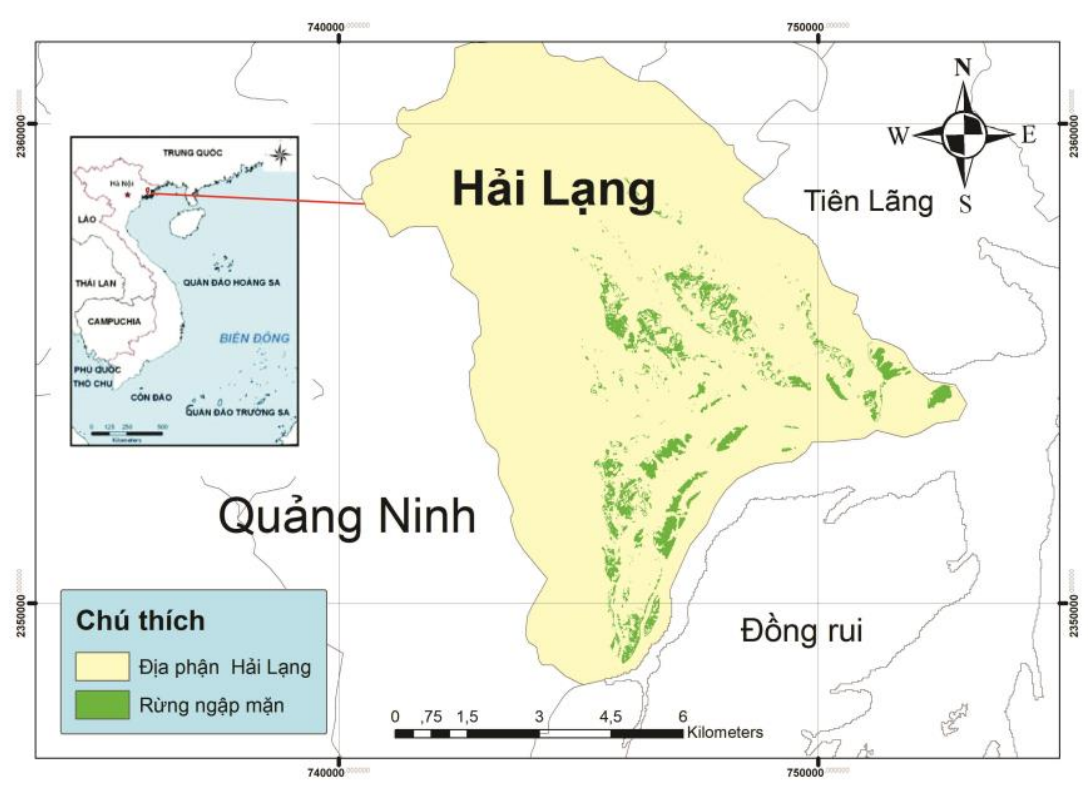

Hình 1. Rừng ngập mặn xã Hải Lạng, huyện Tiên Yên - khu vực nghiên cứu. 
Sinh khối trên mặt đất và dưới mặt đất của ô tiêu chuẩn được tính bằng tổng sinh khối trên mặt đất và dưới mặt đất của tất cả các cây trong ô tiêu chuẩn đó.

Phwơng pháp xác dịnh luọng cacbon tích lũy trong sinh khối của cây và của rùng

Từ sinh khối trên mặt đất và dưới mặt đất của cây và của rừng, xác định lượng cacbon tích lũy trong sinh khối bằng cách nhân sinh khối với hệ số chuyển đổi sinh khối sang cacbon. Đối với trang (Kandelia abovata) hệ số chuyển đổi là 0,4955 ; đối với bần chua (Sonneratia caseolaris) là 0,4953 (Nguyễn Thị Hồng Hạnh và cộng sự, 2016) [3]; đối với các loài cây khác là 0,47 (IPCC, 2006) [4].

Phuơng pháp xác định hàm lương cacbon trong đất

Lấy mẫu đất: Sử dụng khoan lấy mẫu đất của Mỹ với Modem HUNIwilde, có chiều dài $120 \mathrm{~cm}$, lấy mẫu lần lượt từ tầng đất sâu xuống $100 \mathrm{~cm}$, dùng thước đo và lấy đất phân tích ở các độ sâu 0-20 cm, 20-40 cm, 40-60 cm, 60-80 $\mathrm{cm}$. Sau đó đem mẫu đất về Phòng thí nghiệm môi trường, Trường Đại học Tài nguyên và Môi trường Hà Nội để xử lý và phân tích.

Số lượng mẫu đất phân tích là 90 mẫu.

Xác định hàm lượng cacbon hưu co (\%) trong đất: theo phương pháp Chiurin (Lê Văn Khoa và cộng sự, 2000) [5].

Tính lượng cacbon tích lũy trong đất (tấn/ha): Lượng cacbon trong đất được xác định theo công thức Nguyễn Thanh Hà (2004) [6] và Kauffman \& Donato (2012) [7].

$$
\begin{aligned}
\mathrm{A}(\mathrm{H}) & =\sum_{0}^{\mathrm{H}} \mathrm{a}(\mathrm{h}) \times \mathrm{dh} \\
\mathrm{a}(\mathrm{h}) & =\mathrm{c}(\mathrm{h}) \times \frac{\mathrm{T}(\mathrm{h})}{100} \\
\mathrm{C}(\mathrm{H}) & =\mathrm{A}(\mathrm{H}) \times 10^{2}
\end{aligned}
$$

Trong đó: $\mathrm{dh}[\mathrm{cm}]$ là độ sâu của một mẫu đất; $\mathrm{H}[\mathrm{cm}]$ là độ sâu của phẫu diện đất thí nghiệm; $\mathrm{c}(\mathrm{h})[\%]$ là hàm lượng cacbon ở độ sâu $\mathrm{h} ; \mathrm{T}(\mathrm{h})\left[\mathrm{g} / \mathrm{cm}^{3}\right]$ là dung trọng của đất hay khối lượng đất khô không khí trên thể tích đất ở độ sâu $\mathrm{h} ; \mathrm{a}(\mathrm{h})\left[\mathrm{g} / \mathrm{cm}^{3}\right]$ là sự tích lũy cacbon trong đất ở độ sâu $\mathrm{h} ; \mathrm{A}(\mathrm{H})\left[\mathrm{g} / \mathrm{cm}^{2}\right]$ là sự tích lũy cacbon trong đất ở độ sâu $\mathrm{H} ; \mathrm{C}(\mathrm{H})$ [tấn/ha] là sự tích lũy cacbon trong đất của rừng ở độ sâu $\mathrm{H}$.

\section{Kết quả nghiên cứu và thảo luận}

3.1. Mật độ, đường kính thân và chiều cao của cây khu vưc nghiên cứu - co sở xác định sinh khối và lượng cacbon trong sinh khối rùng

Kết quả nghiên cứu về mật độ, đường kính thân, chiều cao của cây được thể hiện qua bảng 2

Kết quả bảng 2 cho thấy, tuyến 2 có mật độ cây là cao nhất với 13300 cây/ha, tiếp theo là tuyến 1 với 9867 cây/ha, thâp nhất là tuyến 3 với 6233 cây/ha. Thành phần loài cây giữa các tuyến cũng có sự khác nhau, tuyến 1 và tuyến 2 có loài ưu thế là vẹt dù $(B$. gymnorhiza), còn tuyến 3 có loài ưu thế là trang (K. obovata).

Đường kính thân cây và chiều cao có sự khác nhau giữa các loài và các tuyến điều tra. Ngay cả khi cùng loài, đường kính thân cây và chiều cao cây cũng có sự khác nhau. Tại các tuyến điều tra, đường kính thân của cây sú $(A$. corniculatum) là thấp nhất. Đường kính thân của cây, có ảnh hưởng nhiều đến sinh khối cây và lượng cacbon trong sinh khối trên mặt đất và dưới mặt đất của cây (Nguyễn Thị Hồng Hạnh và cộng sự, 2016) [3].

\subsection{Lương cacbon tích lüy trong sinh khối trên mặt đất của rù̀ng}

Kết quả phân tích và tính toán lượng cacbon tích lũy trong sinh khối trên mặt đất của rừng ngập mặn xã Hải Lạng, huyện Tiên yên, tỉnh Quảng Ninh được thể hiện trong bảng 3 .

Kết quả bảng 3 cho thấy, vẹt dù $(B$. gymnorhiza) tích lũy cacbon cao nhất đạt 19,59 tấn/ha, tiếp đến là sú (A. corniculatum) và đâng (R. stylosa) đều đạt 2,86 tấn/ha, sau đó là trang ( $K$. obovata $)$ đạt 1,16 tấn/ha và thấp nhất là mắm biển (A. marina) đạt 0,53 tấn/ha. Đánh giá từng tuyến nghiên cứu cho thấy ở tuyến 1 , tổng cacbon tích lũy trong sinh khối trên mặt đất cao nhất đạt 41,87 tấn/ha, tuyến 2 đạt 27,54 tấn/ha và thấp nhất là tuyến 3 đạt 9,53 tấn/ha. 
Bảng 2. Mật độ, đường kính thân, chiều cao của cây rừng khu vực nghiên cứu

\begin{tabular}{lllllllll}
\hline \multirow{2}{*}{$\begin{array}{l}\text { Tuyến } \\
\text { điều tra }\end{array}$} & Cây & $\begin{array}{l}\text { Mật độ } \\
\text { (cây/ha) }\end{array}$ & \multicolumn{2}{l}{ Đường kính thân $(\mathrm{cm})$} & \multicolumn{4}{c}{ Chiều cao $(\mathrm{cm})$} \\
\cline { 5 - 9 } & & Dmax & Dmin & D trung bình & Hmax & Hmin & H trung bình \\
\hline \multirow{4}{*}{ Tuyến 1 } & Vẹt dùu & 7867 & 16,56 & 1,27 & $5,83 \pm 0,96$ & 595,0 & 145,0 & $274,8 \pm 12,5$ \\
& Đước & 67 & 7,34 & 6,73 & $7,03 \pm 0,43$ & 540,0 & 345,0 & $442,5 \pm 137,9$ \\
& Sú & 1634 & 5,65 & 1,83 & $4,28 \pm 0,75$ & 280,0 & 130,0 & $203,3 \pm 36,5$ \\
& Trang & 300 & 9,00 & 4,97 & $7,11 \pm 1,08$ & 325,0 & 235,0 & $282,2 \pm 26,5$ \\
& Vẹt dù & 7100 & 15,68 & 1,37 & $4,38 \pm 0,67$ & 505,0 & 110,0 & $246,7 \pm 29,0$ \\
Tuyến 2 & Đước & 800 & 7,96 & 2,69 & $5,06 \pm 0,37$ & 495,0 & 195,0 & $373,5 \pm 34,2$ \\
& Sú & 3867 & 7,50 & 1,83 & $2,99 \pm 0,94$ & 242,5 & 95,0 & $212,4 \pm 35,5$ \\
& Trang & 1534 & 7,55 & 1,74 & $5,70 \pm 2,62$ & 305,0 & 115,0 & $264,9 \pm 42,6$ \\
& Vẹt dù & 133 & 14,97 & 1,75 & $6,40 \pm 7,43$ & 517,5 & 117,5 & $300,8 \pm 162,6$ \\
& Đước & 1334 & 8,76 & 1,91 & $4,54 \pm 0,82$ & 460,0 & 125,0 & $286,9 \pm 64,2$ \\
Tuyến 3 & Sún & 767 & 3,34 & 1,43 & $2,55 \pm 0,13$ & 247,5 & 95,0 & $167,9 \pm 5,1$ \\
& Trang & 3934 & 10,51 & 1,75 & $4,89 \pm 0,61$ & 350,0 & 110,0 & $233,8 \pm 12,8$ \\
& Mắm & 67 & 14,25 & 10,19 & $12,22 \pm 2,87$ & 347,5 & 342,5 & $345,0 \pm 3,5$ \\
\hline
\end{tabular}

Bảng 3. Lượng cacbon tích lũy trong sinh khối trên mặt đất của rừng ngập mặn xã Hải Lạng, huyện Tiên Yên, tỉnh Quảng Ninh

\begin{tabular}{|c|c|c|c|c|c|c|c|}
\hline \multirow{2}{*}{$\begin{array}{l}\text { Tuyến } \\
\text { điều tra }\end{array}$} & \multirow{2}{*}{$\begin{array}{l}\text { Mật độ } \\
\text { (cây/ha) }\end{array}$} & \multicolumn{5}{|c|}{ Cacbon tích lũy trong sinh khối trên mặt đất (tấn/ha) } & \multirow{2}{*}{$\begin{array}{l}\text { Tổng cac bon } \\
\text { tích lũy trong } \\
\text { sinh khối trên } \\
\text { mặt đất } \\
\text { (tấn/ha) }\end{array}$} \\
\hline & & Vẹt dù & Sú & Đâng & Trang & Mắm & \\
\hline Tuyến 1 & 9867 & $36,03 \pm 1,38$ & $4,92 \pm 0,37$ & $0,57 \pm 0,03$ & $0,34 \pm 0,01$ & 0 & $41,87 \pm 17,17$ \\
\hline Tuyến 2 & 13300 & $21,29 \pm 1,97$ & $2,86 \pm 0,32$ & $2,76 \pm 0,61$ & $0,63 \pm 0,05$ & 0 & $27,54 \pm 9,66$ \\
\hline Tuyến 3 & 6233 & $1,44 \pm 0,01$ & $0,81 \pm 0,21$ & $3,20 \pm 0,22$ & $2,50 \pm 0,26$ & $1,58 \pm 0,02$ & $9,53 \pm 0,94$ \\
\hline $\begin{array}{l}\text { Trung } \\
\text { bình }\end{array}$ & 9800 & $19,59 \pm 13,17$ & $2,86 \pm 1,60$ & $2,86 \pm 1,33$ & $1,16 \pm 1,09$ & $0,53 \pm 0,79$ & $26,31 \pm 18,44$ \\
\hline
\end{tabular}

Như vậy, trung bình cacbon tích lũy trong sinh khối trên mặt đất của toàn bộ khu vực nghiên cứu đạt 26,31 tấn/ha, nhưng có sự biến động khá lớn giữa các tuyến nghiên cứu và giữa các loài cây ngập mặn phân bố tại địa điểm nghiên cứu.

So sánh kết quả nghiên cứu của chúng tôi tại rừng ngập mặn tự nhiên xã Hải Lạng, huyện Tiên Yên, tỉnh Quảng Ninh với nghiên cứu của Nguyễn Thị Hồng Hạnh và cộng sự (2016) [3], trên đối tượng là rừng trồng thuần loài trang $(K$. obovata), hỗn giao hai loài trang và bần chua tại các huyện ven biển đồng bằng Bắc Bộ cho thấy, lượng cacbon tích lũy trong sinh khối trên mặt đất của rừng tự nhiên tại xã Hải Lạng thấp hơn so với rừng trồng. Nguyên nhân có thể là do mật độ của rừng tự nhiên thấp hơn mật độ của rừng trồng. Kết quả của bảng 2 cho thấy, mật độ của rừng tự nhiên tại xã Hải Lạng dao động trong khoảng $(6233$ - 13300) cây/ha, tuy nhiên đối với rừng trang trồng $3-5$ tuổi mật độ dao động trong khoảng (18600 - 19600) cây/ha, rừng trang 10 - 13 tuổi mật độ dao động trong khoảng $(15800$ - 19500) cây/ha, rừng trồng hỗn giao trang và bần chua $10-13$ tuổi có mật độ dao động trong khoảng (7228 - 14424) cây/ha 
(Nguyễn Thị Hồng Hạnh và cộng sự (2016) [3]. Ngoài ra, đặc điểm sinh học của các loài cây cũng có sự khác nhau. Kết quả điều tra cho thấy, cây sú $(A$. corniculatum) có đường kính thân và chiều cao thấp hơn so với các loài cây ngập mặn khác (bảng 2), do đó tuyến 2 mặc dù có mật độ cao hơn so với tuyến 1 và tuyến 3 , nhưng số lượng cây sú nhiều hơn các tuyến khác, do đó lượng cacbon trong sinh khối trên mặt đất thấp hown các tuyến khác.

\subsection{Lương cacbon tích lũy trong sinh khối dưới mặt đất của rùng}

Sinh khối dưới mặt đất của cây bao gồm sinh khối của toàn bộ rễ cây. Kết quả nghiên cứu lượng cacbon tích lũy trong sinh khối dưới mặt đất của cây được thể hiện qua bảng 4 .

Tương tự như lượng cacbon tích lũy trong sinh khối trên mặt đất của rừng. Sinh khối dưới mặt đất của quần thể vẹt dù cao nhất đạt 19,04 tấn/ha, tiếp đến là quần thể đước đạt 2,31 tấn/ha, tiếp theo là quần thể sú đạt 2,14 tấn/ha, quần thể trang và mắm có lượng cacbon tích lũy trong sinh khối dưới mặt đất thấp nhất lần lượt là 0,45 tấn/ha và 0,42 tấn/ha.

So sánh khả năng tích lũy cacbon trong sinh khối dưới mặt đẩt của các tuyến nghiên cứu thu được kết quả như sau: tuyến 1 tích lũy cacbon dưới mặt đất lớn nhất với lượng cacbon tích lũy đạt 38,11 tấn/ha, tuyến 2 đạt 27,75 tấn/ha và thấp nhất là tuyến 3 với 7,20 tấn/ha. Nguyên nhân có sự khác biệt này là do sự phân bố của các loài không đồng đều, đặc điểm sinh học của bộ rễ của từng loài là khác nhau. Theo kết quả nghiên cứu của Nguyễn Thị Hồng Hạnh và cộng sự (2016) [3], lượng cacbon tích lũy trong sinh khối dưới mặt đất của quần thể trang cũng thấp hơn quần thể bần chua trong rừng trồng hỗn giao 2 loài trang và bần chua. Đồng thời, mật độ cũng là một trong những yếu tố ảnh hưởng đến lượng cacbon tích lũy trong sinh khối của rừng.

So sánh lượng cacbon tích lũy trong sinh khối trên mặt đất (bảng 2) với lượng cacbon tích lũy trong sinh khối dưới mặt đất của rừng thấy, lượng cacbon tích lũy trong sinh khối trên mặt đất của rừng cao hơn lượng cacbon tích lũy trong sinh khối dưới mặt đất của rừng. Kết quả nghiên cứu này tương tự kết quả nghiên cứu của Nguyễn Thị Hồng Hạnh và cộng sự (2016) [5] khi nghiên cứu định lượng cacbon trong rừng ngập mặn trồng ven biển đồng bằng Bắc Bộ.

\subsection{Lương cacbon tích lũy trong đất rùng}

Lượng cacbon (tấn/ha) tích lũy trong đất rừng có sự khác nhau giữa các tầng đất, lượng cacbon tích lũy cao ở lớp đất bề mặt và giảm ở các độ sâu khác nhau của đất (bảng 5).

Bảng 4. Cacbon tích lũy trong sinh khối dưới mặt đất của rừng ngập mặn xã Hải Lạng, huyện Tiên Yên, tỉnh Quảng Ninh

\begin{tabular}{lllllll}
\hline \multirow{2}{*}{$\begin{array}{l}\text { Tuyến } \\
\text { điều tra }\end{array}$} & \multicolumn{4}{c}{ Cacbon tích lũy trong sinh khối dưới mặt đất (tấn/ha) } & & $\begin{array}{l}\text { Tổng cacbon } \\
\text { tích lũy trong } \\
\text { sinh khối dưới } \\
\text { mặt đất (tấn/ha) }\end{array}$ \\
\cline { 2 - 8 } & Vẹt dù & Sú & Đâng & Trang & Mắm & $38,11 \pm 17,25$ \\
Tuyến 1 & $35,37 \pm 1,12$ & $2,19 \pm 0,16$ & $0,41 \pm 0,01$ & 0,14 & 0 & $27,75 \pm 9,27$ \\
Tuyến 2 & $20,65 \pm 1,44$ & $3,88 \pm 0,35$ & $2,98 \pm 0,49$ & $0,24 \pm 0,02$ & 0 & $7,20 \pm 1,23$ \\
Tuyến 3 & $1,09 \pm 0,01$ & $0,33 \pm 0,07$ & $3,54 \pm 0,23$ & $0,98 \pm 0,11$ & $1,26 \pm 0,02$ & \\
Trung binh & $19,04 \pm 13,03$ & $2,14 \pm 1,75$ & $2,31 \pm 1,52$ & $0,45 \pm 0,43$ & $0,42 \pm 0,63$ & $24,35 \pm 18,14$ \\
\hline
\end{tabular}


Bảng 5. Lượng cacbon tích lũy trong đất rừng ngập mặn xã Hải Lạng, huyện Tiên Yên, tỉnh Quảng Ninh

\begin{tabular}{|c|c|c|c|c|c|c|}
\hline \multirow{2}{*}{$\begin{array}{l}\text { Tuyến } \\
\text { điều tra }\end{array}$} & \multicolumn{5}{|c|}{ Cacbon tích lũy (tấn/ha) trong các tầng đất } & \multirow{2}{*}{$\begin{array}{l}\text { Tổng cacbon } \\
\text { tích lũy trong } \\
\text { đất }(0-100 \\
\mathrm{cm})(\text { tấn/ha) }\end{array}$} \\
\hline & $0-20 \mathrm{~cm}$ & $20-40 \mathrm{~cm}$ & $40-60 \mathrm{~cm}$ & $60-80 \mathrm{~cm}$ & $80-100 \mathrm{~cm}$ & \\
\hline Tuyến 1 & $37,96 \pm 0,64$ & $35,49 \pm 0,83$ & $24,19 \pm 0,99$ & $21,34 \pm 0,75$ & $15,77 \pm 0,42$ & $134,75 \pm 3,63$ \\
\hline Tuyến 2 & $35,76 \pm 0,74$ & $29,08 \pm 0,85$ & $24,10 \pm 1,44$ & $18,65 \pm 0,91$ & $17,96 \pm 0,72$ & $125,56 \pm 4,65$ \\
\hline Tuyến 3 & $28,04 \pm 0,66$ & $25,05 \pm 0,76$ & $23,83 \pm 1,51$ & $20,13 \pm 1,05$ & $17,25 \pm 0,27$ & $114,25 \pm 4,26$ \\
\hline Trung bình & $33,92 \pm 4,69$ & $29,86 \pm 4,77$ & $24,04 \pm 1,05$ & $20,04 \pm 1,4$ & $16,99 \pm 1,07$ & $124,85 \pm 9,74$ \\
\hline
\end{tabular}

Kết quả nghiên cứu trong bảng 4 cho thấy, lượng cacbon tích lũy chủ yếu ở lớp đất bề mặt $0-20 \mathrm{~cm}$, lượng cacbon tích lũy giữa các tuyến giao động trong khoảng $(28,04-37,96)$ tấn/ha, lượng cacbon giảm dần ở các độ sâu tiếp theo, thấp nhất trong nghiên cứu này là lượng cacbon tích lũy trong đất ở độ sâu $80-100 \mathrm{~cm}$ với khoảng $(15,77-17,96)$ tấn/ha. Sự tích lũy cacbon trong đất chủ yếu trên lớp đất bề mặt là do đất rừng ngập mặn luôn nhận được lượng cacbon từ lượng rơi (cành, lá, ... rụng) của rừng, lượng cacbon từ phù sa của sông và lượng cacbon từ trầm tích mang đến nhờ thủy triều. Ngoài ra, đất rừng ngập mặn còn nhận được một lượng cacbon từ rễ của cây rừng. Lượng cacbon tích lũy trong đất giảm dần theo độ sâu của đất, tích lũy cao ở lớp đất bề mặt và giảm dần theo độ sâu của đất, nguyên nhân là do quá trình sunfat hóa các chất hữu cơ và hô hấp kỵ khí của đất (Nguyễn Thị Hồng Hạnh, 2009) [8].

Tổng lượng cacbon tích lũy trong đất (tấn/ha) ở tuyến 1 là cao nhất đạt 134,75 tấn/ha, tiếp theo là tuyến 2 đạt 125,56 tấn/ha, thấp nhất là tuyến 3 với 114,25 tấn/ha (hình 2).

Tổng lượng cacbon tích lũy trong đất có sự khác nhau giữa các tuyến nghiên cứu, nguyên nhân là do mật độ của cây rừng tuyến 1 cao hơn so với mật độ của tuyến 2 và tuyến 3 (bảng 2), nhận định này phù hợp với kết quả nghiên cứu của Nguyễn Thị Hồng Hạnh (2009) [8], Nguyễn Thị Hồng Hạnh và cộng sự (2016) [3].

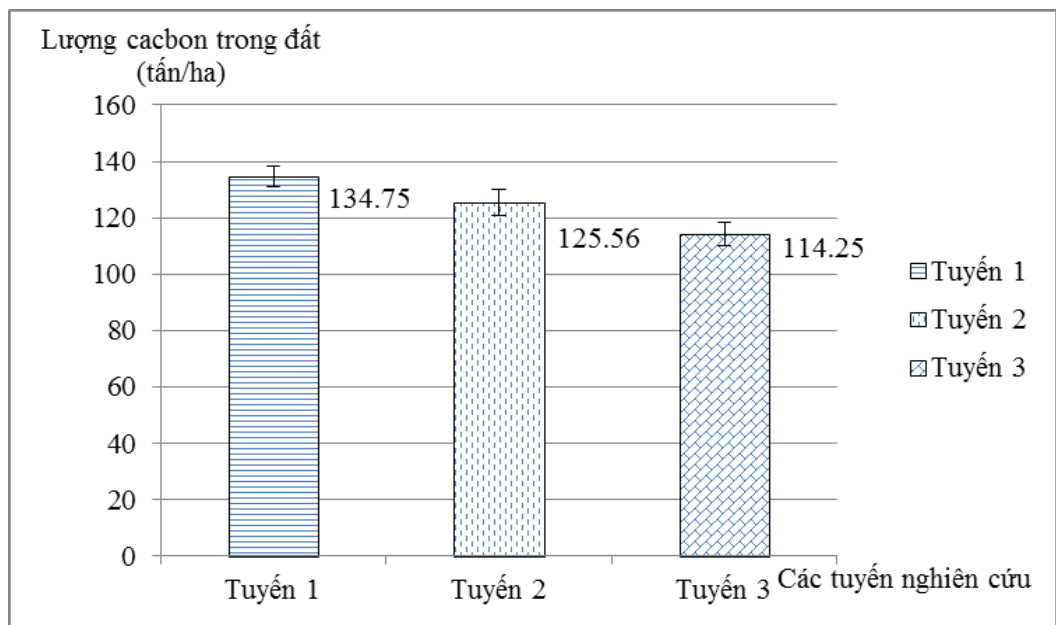

Hình 2. Tổng lượng cacbon (tấn/ha) tích lũy trong đất $(0-100) \mathrm{cm}$ của rừng ngập mặn xã Hải Lạng, huyện Tiên Yên, tỉnh Quảng Ninh. 


\subsection{Tổng luợng cacbon tích lũy trong rù̀ng ngập mặn xã Hải Lạng, huyện Tiên Yên, tỉnh Quảng Ninh}

Từ kết quả nghiên cứu về lượng cacbon tích lũy trong sinh khối trên, dưới mặt đất của rừng (bảng 2 , bảng 3 ) và lượng cacbon tích lũy trong đất rừng (bảng 4), theo hướng dẫn của IPCC (2006), đánh giá khả năng tạo bể chứa cacbon của rừng ngập mặn xã Hải Lạng, huyện tiên Yên, tỉnh Quảng Ninh thông qua 3 bể chứa cacbon như sau:

Bảng 6. Tổng cacbon tích lũy trong rừng ngập mặn xã Hải Lạng, huyện Tiên Yên, tỉnh Quảng Ninh

\begin{tabular}{|c|c|c|c|c|c|}
\hline \multirow{2}{*}{$\begin{array}{l}\text { Tuyến điều } \\
\text { tra }\end{array}$} & \multicolumn{3}{|c|}{ Lượng cacbon tích lũy (tấn/ha) } & \multirow{2}{*}{$\begin{array}{l}\text { Tổng cacbon } \\
\text { tích lũy trong } \\
\text { rừng ngập mặn } \\
\text { (tấn/ha) }\end{array}$} & \multirow{2}{*}{$\begin{array}{l}\text { Tổng } \mathrm{CO}_{2} \text { hấp } \\
\text { thư tương ưng } \\
\text { (tấn/ha) }\end{array}$} \\
\hline & $\begin{array}{l}\text { Trong sinh khối } \\
\text { thực vật trên } \\
\text { mặt đất }\end{array}$ & $\begin{array}{l}\text { Trong sinh khối } \\
\text { thực vật dưới mặt } \\
\text { dất }\end{array}$ & Trong đất & & \\
\hline Tuyến 1 & $41,87 \pm 17,17$ & $38,11 \pm 17,25$ & $134,75 \pm 3,63$ & 214,72 & 788,04 \\
\hline Tuyến 2 & $27,54 \pm 9,66$ & $27,75 \pm 9,27$ & $125,56 \pm 4,65$ & 180,85 & 553,72 \\
\hline Tuyến 3 & $9,53 \pm 0,94$ & $7,20 \pm 1,23$ & $114,25 \pm 4,26$ & 130,98 & 480,69 \\
\hline Trung bình & $26,31 \pm 18,44$ & $24,35 \pm 18,14$ & $124,85 \pm 9,74$ & $175,52 \pm 38,13$ & $607,48 \pm 114,39$ \\
\hline
\end{tabular}

Kết quả nghiên cứu trong bảng 6 cho thấy, tuyến 1 có lượng cacbon tích lũy cao nhất là 214,72 tấn/ha (tương ứng với lượng $\mathrm{CO}_{2}$ là 788,04 tấn/ha), tiếp theo là tuyến 2 có lượng cacbon tích lũy là 180,85 tấn/ha (tương ứng với lượng $\mathrm{CO}_{2}$ là 553,72 tấn/ha) và thấp nhất là tuyến 3 có lượng cacbon tích lũy là 130,98 tấn/ha (tương ứng với lượng $\mathrm{CO}_{2}$ là 480,69 tấn/ha).

So sánh lượng cacbon tích lũy trong 3 bể chứa cacbon thấy, lượng cacbon tích lũy trong đất rừng cao hơn so với lượng cacbon tích lũy trong sinh khối thực vật trên mặt đất và dưới mặt đất. Kết quả nghiên cứu này tương tự kết quả nghiên cứu của Nguyễn Thị Hồng Hạnh (2009) [8], Fujimoto và cộng sự (2000) [9], Nguyễn Thị Hồng Hạnh và cộng sự (2016) [3]. Theo Albright (1976) [10], Fujimoto và cộng sự (2000) [9] cho rằng, sự tích lũy cacbon trong đất rừng ngập mặn là thuận lợi bởi sự phân hủy chậm các chất hữu cơ trong đất (chủ yếu là rễ), $90 \%$ lá bị phân hủy trong vòng gần 7 tháng nhưng $50-88 \%$ mô rễ vẫn giữ được trong một năm, khi rễ bị chôn vùi trong đất thì tốc độ phân hủy rễ còn chậm hơn nữa. Hàm lượng cacbon tích lũy trong đất rừng ngập mặn khá cao (trung bình khoảng 97,57 tân/ha) so với rừng mưa nhiệt đới $(29,5$ tấn/ha). Sở dĩ như vậy vì hầu hết lượng rơi thực vật trên sàn rừng mưa nhiệt đới đều được phân hủy nhanh chóng và tích lũy không nhiều trên sàn rừng, trong khi đó rừng ngập mặn với lượng trầm tích và ngập nước triều thường xuyên đã làm giảm hoặc chậm quá trình phân hủy lượng rơi xác thực vật. Lượng cacbon tích lũy phần lớn trong trầm tích của rừng.

Như vậy, có thể nói đất rừng ngập mặn có khả năng tích lũy một lượng lớn cacbon, tạo bể chứa cacbon góp phần làm giảm khí thải gây hiệu ứng nhà kính.

Như vậy, kết quả nghiên cứu định lượng cacbon trong rừng ngập mặn huyện Tiên Yên, tỉnh Quảng Ninh cho thấy, rừng ngập mặn lưu trữ cacbon trong sinh khối thực vật trên mặt đất, dưới mặt đất và trong đất rừng, đóng vai trò như một bể chứa $\mathrm{CO}_{2}$ - khí nhà kính. Kết quả nghiên cứu bước đầu cung cấp những thông tin và số liệu về khả năng tích lũy cacbon trong rừng ngập mặn tự nhiên, giúp nhà quản lý đưa ra những chiến lược phát triển, quản lý rừng ngập mặn và bảo vệ môi trường dựa trên cơ sở phát triển bền vững, đồng thời cung cấp cơ sở cho việc đàm phán quốc tế trong các chương trình thực hiện cắt giảm khí nhà kính. 


\section{Kết luận}

1. Lượng cacbon tích lũy trong sinh khối thực vật trên mặt đất, dưới mặt đất của rừng ngập mặn xã Hải Lạng, huyện Tiên Yên, tỉnh Quảng Ninh như sau:

Lượng cacbon tích lũy trong sinh khối thực vật trên mặt đất của rừng trung bình là $(26,31 \pm 18,44)$ tấn/ha.

Lượng cacbon tích lũy trong sinh khối thực vật dưới mặt đất của rừng trung bình là $(24,35 \pm 18,14)$ tấn/ha.

2. Lượng cacbon tích lũy trong đất rừng trung bình là $(124,85 \pm 9,74)$ tấn/ha. Lượng cacbon tích lũy trong đất rừng cao hơn khoảng 5 lần lượng cacbon tích lũy trong sinh khối thực vật trên mặt đất và dưới mặt đất của rừng.

3. Tổng lượng cacbon tích lũy thông qua 3 bể chứa cacbon của rừng: (1) Bể chứa cacbon trong thực vật ở trên mặt đất; (2) Bể chứa cacbon trong thực vật ở dưới mặt đất; (3) Bể chứa cacbon trong đất đạt trung bình là $(175,52 \pm 38,13)$ tấn/ha (tương ứng với lượng CO2 là $(607,48 \pm 114,39)$ tấn/ha. Khả năng tích lũy cacbon trong rừng cao là cơ sở khoa học để xây dựng và thực hiện các dự án trồng rừng ngập mặn, kết hợp với bảo tồn, quản lý bền vững và tăng cường trữ lượng cacbon rừng trồng ở các dải ven biển Việt Nam.

\section{Lời cảm ơn}

Nghiên cứu được hoàn thành dưới sự hỗ trợ kinh phí của đề tài mã số TNMT.2018.05.06. Các tác giả xin trân trọng cảm ơn.

\section{Tài liệu tham khảo}

[1] Nguyen Thi Hong Hanh, Pham Hong Tinh, Mai Sy Tuan, 2016. Allometry and biomass accounting for mangroves Kandelia obovata Sheue, Liu \& Yong and Sonneratia caseolaris (L.) Engler planted in coastal zone of red river delta, Vietnam, International Journal of Development Research Vol.06, Issue, 05 (2016): 7804-7808.
[2] Komiyama A., Ong J.E., Poungparn S., 2008. Allometry, biomass, and productivity of mangrove forests: A review, Aquatic Botany, 89: 128-137.

[3] Nguyễn Thị Hồng Hạnh (Chủ nhiệm), Bùi Thị Thư, Nguyễn Thị Hoài Thương, Vũ Văn Doanh, Lê Đắc Trường, Hoàng Thị Huê, Lê Thu Thủy, Đinh Văn Thuận, Phạm Hồng Tính, Nguyễn Xuân Tùng, 2016. Nghiên cứu định lượng cacbon tích lũy để đánh giá khả năng tạo bể chứa cacbon của rừng ngập mặn ở vùng ven biển Đồng bằng Bắc Bộ, Đề tài Khoa học và Công nghệ cấp Bộ, mã số: TNMT.04.57/10-15.

[4] IPCC, 2006. IPCC Guidelines for National Greenhouse Gas Inventories, Prepared by National Greenhouse Gas Inventories Programme, Eggleston H.S., Buendia L., Miwa K., Ngara T., Tanabe K., (eds). Published: IGES, Japan.

[5] Lê Văn Khoa, Nguyễn Xuân Cự, Bùi Thị Ngọc Dung, Lê Đức, Trần Khắc Hiệp, Cái Văn Tranh, 2000. Phương pháp phân tích đất, nước, phân bón, cây trồng. Nhà xuất bản Giáo dục: 71-74.

[6] Nguyen Thanh Ha, Yoneda R., Ninomiya I., Harada K., Tan D. V., Tuan M. S., Hong P. N., 2004. The effects of stand-age and inundation on the carbon accumulation in soil of mangrove plantation in Namdinh, northern Vietnam, The Japan society of tropical ecology, 14 (2004): 2137.

[7] Kauffman J. B., \& Donato D., 2012. Protocols for the measurement, monitorring and reporting of structure, biomass and carbon stocks in mangrove forests. Bogor, Indonesia: Center for International Forestry Research (CIFOR).

[8] Nguyễn Thị Hồng Hạnh, 2009. Nghiên cứu khả năng tích lũy cacbon của rừng trang (Kandelia obovata Sheue, Liu \& Yong) trồng ven biển huyện Giao Thủy, tỉnh Nam Định. Luận án tiến sĩ sinh học, Trường Đại học Sư phạm Hà Nội.

[9] Fujimoto K., Miyagi T., Murofushi T., Adachi H., Komiyama A., Mochida Y., Ishihara S., Pramojanee P., Srisawatt W., Havanond S., 2000. "Evaluation of the belowground carbon sequestration of estuarine mangrove habitats, Southwestern Thailand", In: Miyagi T. (ed.) Organic material and sea-level change in mangrove habitat, Tohoku-Gakuin University, Sendai, 980-8511, Japan, pp. 101-109.

[10] Albright L.J., 1976. In situ degradation of mangrove tissues (Note), N. Z. Journal of Marine and Freshwater Research 10, pp. 385-389. 


\title{
Study on Quantification of Carbon Stock in Mangrove Forest along the Coast of Hai Lang Commune, Tien Yen District, Quang Ninh Province
}

\author{
Nguyen Thi Hong Hanh ${ }^{1}$, Le Khanh Linh ${ }^{2}$, Pham Hong Tinh ${ }^{1}$, \\ Le Dac Truong ${ }^{1}$, Bui Thi Thu ${ }^{1}$, Truong Minh Tam ${ }^{3}$ \\ ${ }^{1}$ Hanoi University of Natural Resources and Environment \\ ${ }^{2}$ Department of Natural Resources and Environment, Moc Chau District \\ ${ }^{3}$ General Department of Environment
}

\begin{abstract}
In order to assess mangrove carbon sink for state management of greenhouse gas emissions/sequestration, provide a scientific and basis for implementing greenhouse gas reduction programs, e.g. REDD, REDD ${ }^{+}$, carbon stocks in three carbon pools, 1) above ground biomass, 2) below ground biomass and 3) soil were quantified for mangrove forest with dominant species of Rhizophora stylosa, Bruguiera gymnorhiza, Kandelia obovata, Aegiceras corniculatum, Avicennia marina in Hai Lang Commune, Tien Yen District, Quang Ninh Province, following the guideline by IPCC (2006). The results show that carbon accumulated in mangrove soil is about five times higher than the biomass carbon (above ground biomass and below ground biomass). The carbon accumolated in the soil was 124.85 tons/ha; the carbon accumulated in above ground biomass was 26.31 tons/ha; and the carbon accumulated in below ground biomass was 24.35 tons/ha. The total carbon stock in three carbon pools was 175.52 tonnes/ha (corresponding to 607.48 tons of $\mathrm{CO}_{2}$ sequestrated by one hectare of the mangroves). Large amount of carbon sequestrated in mangrove forest is a scientific basis for the development and implementation of mangrove afforestation projects, combined with conservation, sustainable management of mangroves, and the enhancement of mangrove carbon stocks in the coastal areas of Vietnam.
\end{abstract}

Keywords: Avicennia marina, Aegiceras corniculatum, Bruguiera gymnorhiza, Kandelia obovata, Rhizophora stylosa, greenhouse gases, mangrove forest, carbon sequestration. 